\title{
Zooasistence v pedagogické praxi
}

\author{
Kateřina Jančaříková \\ Envigogika 2009/IV/3 - Recenzované články/ Reviewed Papers \\ Publikováno/Published 22. 12. 2009
}

DOI: http://dx.doi.org/10.14712/18023061.44

\begin{abstract}
Abstrakt:
Rozvoj terapeuticky nebo pedagogicky podporovaných humánně-animálních interakcí se stává ve všech zemí EU jednou z cest zmírňování prohlubujícího se odcizování člověka prírodě. Tento článek seznamuje $s$ terminologií a problematikou zooasistence a představuje kvalitativní výzkum uskutečnění na školách v České republice, který upozorňuje na spontánní trend "návratu k chovatelství" na českých školách, upozorňuje na jeho rizika a doporučuje prostředky, jak zefektivnit tuto AAE (Animal Assisted Education). $\mathrm{Na}$ základě zde prezentovaného výzkumu byl vytvořen na Pedagogické fakultě UK v Praze postgraduální kurz Potenciál zooasistencí v pedagogické praxi, který byl akreditován MŠMT $\checkmark$ rámci programu celoživotního vzdělávání.
\end{abstract}

\section{Klíčová slova:}

Zooterapie, zooasistence, humánně-animální interakce, řízený a spontánní rozvoj osobnosti, individuální i skupinová stimulace, návštěvní environmentální programy, ekopsychologie

\begin{abstract}
:
We can see the development of human-animal interaction (by therapy or pedagogy) in the countries of the EU.

The development is a way of reducing human alienation of the process of nature.

The article presents terminology and zooasistence problems as well as presenting qualitative research undertaken in Czech schools. The research points to a spontaneous "pet trend" in Czech schools, describes its risks and recommends what to do so that AAE (Animal Assisted Education) will be more effective. There is a new course The Potential of Zooasistance in the Process of Education, which has been accredited at Charles University - Faculty of Education.
\end{abstract}

\section{Key words:}

Zootherapy, Animal Assisted Activities, Animal Assisted Education, interaction between children and animals, direct and indirect contacts, spontaneous behaviour of child and animal, personality stimulation, visiting environmental and zooaistented programmes, concervation psychology 
Rozvoj terapeuticky nebo pedagogicky podporovaných humánně-animálních interakcí se stává ve všech zemí EU jednou z cest zmírňování prohlubujícího se odcizování člověka přírodě. Tento článek seznamuje s terminologií a problematikou zooasistence a představuje kvalitativní výzkum uskutečnění na školách v České republice, který upozorňuje na spontánní trend "návratu k chovatelství" na českých školách, upozorňuje na jeho rizika a doporučuje prostředky, jak zefektivnit tuto AAE (Animal Assisted Education). Na základě zde prezentovaného výzkumu byl vytvořen na Pedagogické fakultě UK v Praze postgraduální kurz Potenciál zooasistencí v pedagogické praxi, který byl akreditován MŠMT v rámci programu celoživotního vzdělávání.

Odcizení od přírody, změna životního stylu, vyšší nároky ve škole, nedostatek pohybu $v$ prrírodě a také nedostatek práce na čerstvém vzduchu, to vše je zdrojem stresu, který (především městské) děti zažívají (Sak, 2000). Výzkumy ukazují, že tento stres je možné odbourávat mimo jiné také prostřednictvím kontaktu se zvířaty, resp. přírodou, a opakovaně prokázaly, že kontakt s živým tvorem zvyšuje dětem sebevědomí, napomáhá řešit sociální i školní obtíže. Lidem, kteří se mazlili s domácími zvířaty, stoupaly hladiny endorfinů a dalších látek ovlivňujících pocit spokojenosti, pohody a štěstí. Hyperstudie těchto výzkumů Zvířata a naše mentální zdraví vyšla nedávno i v češtině (Odendaal, 2007) jako studijní materiál pro nově otevřený předmět Zoorehabilitace a aktivity se zvíraty pro rozvoj osobnosti na České zemědělské univerzitě (Svobodová et al, 2008). Výzkumy tohoto typu a intuitivní poznatky z praxe ("ono to funguje") iniciovaly nový trend na pomezí psychologie, medicíny, biologie (chovatelství) a pedagogiky - trend zooasistencí, zooterapií a zoorehabilitací. V tomto článku bude tento nový trend představen jako jedna z cest vedoucích $\mathrm{k}$ zefektivňování vzdělávání a také bude představen výzkum, který předcházel akreditaci kurzu Potenciál zooasistencí $v$ pedagogické praxi na UK-PedF v rámci Celoživotního vzdělávání koncem roku 2009.

\section{Použitá terminologie}

Zooterapie x zooasistence - zásadní terminologický rozdíl mezi termínem zooasistence a zooterapie spočívá v osobě, která humánně-animální interakci koordinuje. Zooasistenci může provádět pedagog, psycholog nebo psovod (zoolog), zatímco zooterapii mưže provádět pouze terapeut (fyzioterapeut), př́padně tým fyzioterapeut + psycholog + psovod (zoolog). Ve skutečnosti (neodbornou veřejností i praktiky) se oba tyto termíny často zaměňují, resp. je stále nevhodně používán termín „-terapie".

Zooasistence - v českém jazyce používaný termín zooasistence je $v$ zahraniční literatuře diferencován na:

AAA (Animal Assisted Activities) - spontánní kontakt člověka a zvířete zaměřený na zlepšení kvality života klienta nebo přirozený rozvoj jeho sociálních dovedností. Hlavním cílem je obecná aktivizace klienta. Typickými technikami jsou hlazení zvírete (dotyky), hry, péče o zvíře, přirozené procvičování komunikace a paměti apod. AAA se požívá ve stacionářích, domovech dưchodců, v psychiatrických léčebnách a v léčebnách dlouhodobě nemocných.

AAE (Animal Assisted Education) - spontánní nebo cílený kontakt člověka a zvířete zaměřený na rozšiření nebo zlepšení výchovy, vzdělávání nebo sociálních dovedností klienta. Hlavním cílem je přirozené zvýšení motivace k učení a osobnímu rozvoji, resp. rozvoji kolektivu, ve kterém AAE probíhá. Typickými technikami je předávání informací zábavnou formou a názornou ukázkou, využití zvířete jako prostředníka pro výuku, hry nebo manipulace se zvířetem pro rozvoj motoriky, komunikace. Prítomnost zvířete je využívána jako motivace k učení a také jako "ledolamka" při komunikačních bariérách, at' již na úrovni učitel-žák nebo žák-žák. Pro AAE se používají nejen psi, kočky, koně, ale i bezobratlí nebo hmyz (tzv. insektoterapie). 
Canis-terapie/-asistence - využití kontaktu se psem. Psovodi (popř. s terapeuty) vodí speciálně vybrané a vycvičené psy mezi postižené děti, do nemocnic i do škol k zdravým dětem. Někteří psi volně pobíhají, olizují, vrtí ocasem a všelijak jinak dávají najevo přízeň a rozveselují mysl, jiní vyskočí ke klientovi do postele a trpělivě mu zahřívají bolavé místo a pưsobí pozitivně na svalový tonus (Chvátalová, 2003, Galajdová, 1999). Existují velmi zajímavé kasuistiky využití canisasistence ve speciální pedagogice. Zajímavá je patnáctiletá zkušenost s využíváním psů v logopedické klinické praxi - pes je prostředníkem mezi logopedem a dítětem s elektivním mutismem, cviky, které pes provádí při vyslovení hlásek $\breve{R}, \mathrm{R}$ apod. motivují dítě $\mathrm{k}$ jejich radostnějšímu nácviku (Bajtlerová, 2008). V tomto př́spěvku bude představen asistenční pes Tomík, který sedmým rokem doprovází učitelku prvního stupně ZŠ a zlepšuje psychosociální klima třídy.

Felino-terapie/-asistence - využití kontaktu s kočkou. Asistenti nebo terapeuti vodí vybrané kočky do léčeben dlouhodobě nemocných a dalších zařízení, ve kterých je výhodou menší hmotnost zvířete. Současné výzkumy se zabývají studiem vlivu kočičího předení na biorytmy člověka (srdeční a dechová frekvence).

Hipo -terapie/-asistence - využití kontaktu s koněm. Kontakt $s$ koněm je efektivním způsobem rehabilitace dětí po dětské mozkové obrně a dětí jinak motoricky postižených. Je dokázané, že svalový tonus koně při klusu pozitivně stimuluje srdeční činnost jezdce (Dvořáková, Janura, 2008).

Návštěvní program - pravidelné návštěvy zooterapeutického týmu v zařízeních nebo $v$ domácnosti klienta, který si přeje provozovat zooterapeutickou činnost (Velemínský, 2007).

\section{Třídní (školní) chov - dlouhodobý chov zřízený s cílem zlepšit kvalitu vzdělávání a výchovy nebo psychosociálního klimatu třídy.}

Welfare - pohodlí zvířete (at' již chovaného nebo v návštěvním programu). Welfare zahrnuje dostatek jídla, stálý prístup k vodě, vhodnou ubikaci, přiměřené množství podnětů, umožnění sociálního života a dostatečného odpočinku.

\section{Humánně animální interakce včera a dnes}

$V$ posledních několika letech došlo i u nás $\mathrm{k}$ velké změně chápání humánněanimálních interakcí. Ještě M. Kučera (2005) vidí vztah dítě - živý tvor pouze jako kompenzaci dosud neukojeného sexuálního libida (Kučera, 2005: str. 192) a M. Vágnerová (2000) se vztahem dítě-živý tvor (především pes) zabývá okrajově; uvádí ovšem alespoň základní pozitiva tohoto vztahu: stimulace učení, pečovatelského chování, rozvoj sociálních kontaktů (zvíře bud' jako náhradník vrstevníků, nebo prostředek, jak vrstevníky zaujmout), zdroj citové jistoty a bezpečí (Vágnerová, 2000: str. 200). J. Šípek (2000) se věnuje tzv. projektivním metodám a imaginacím, z nichž některé staví na prírodních motivech, např. motivu stromu a jeho zasazení do krajiny, který ovšem nepoužívá jako metodu "léčba přírodou", ale jako nástroj sebepoznání (Šípek, 2000: str. 90).

Dnes je zvíře stále častěji nahlíženo novým zpưsobem - jako partner - společník a prostředník osobnostního rozvoje jedince nebo zlepšení psychosociálního klimatu skupiny. Naše civilizace se tak navrací k myšlení a chování některých přírodních národů, které často navazovaly vztahy nejen humánní (člověk-člověk), ale také humánně-animální (člověk-zvíře). Indiáni např́klad chápali „bratrství" nejen jako pokrevní svazek, ale také jako svazek totemický (příslušnost k určitému totemu). Pokud se ocitli bratři a totemoví bratři ve sporu, totemová příslušnost měla přednost před pokrevenstvím, a to i když osobu se stejným totemem viděla dotyčná osoba ve sporu poprvé v životě. Totemická univerzalizace boří nejenom rodové či kmenové hranice, ale boří také hranice lidství, ve smyslu nikoli sociologickém, ale biologickém, protože totemická jména (a práva) 
nenáleží jenom lidem, ale také některým zvířatům. Tak je tomu např. u australských kmenů z Yorského poloostrova, kteří označují psy jako bratry či syny, nebo u indiánů Iowatů a Winnebagů a jejich psů a koní (Lévi-Strauss, 1996). Podobný „nový" př́stup ke zvířatům, přístup bořící hranice mezi člověkem a zvířetem, praktikoval ochránce a dokumentarista medvědů na Aljašce T. Treadwell (Herzog, 2005), jehož př́běh se stal př́během kultovním, a mnoho dalších hrdinů (např. Nikolaj Vitalijenko, Christopher McCandless nebo románový hrdina Nikolaje Baturina). Mưžeme sledovat rozvoj nové psychologie - tzv. ekopsychologie ( $v$ zahraničí conservation psychology), která se zabývá redefinicí vztahu člověk-zvíre. Dopad tohoto inovativního přístupu mưže být jak pozitivní (zvyšování environmentální senzitivity, odklon od altruistického postoje), tak negativní (neporozumění přirozeným zákonům př́rody a jejich popírání - časté je např. popírání potravního řetězce a smrti, které ve své podstatě prohlubuje proces odcizování přírodě a zvyšuje ekologickou stopu).

\section{Výzkum pozitiv a negativ chovu zvířat ve škole}

\section{Metodologie}

Hlavním cílem tohoto kvalitativního výzkumu bylo získat data a informace o spontánních zooasistencích (AAE) probíhajících v českých školách.

\section{Výzkum byl prováděn těmito kvalitativními výzkumnými nástroji:}

Rozhovory: Celkem bylo uskutečněno 50 rozhovorů s pedagogickými pracovníky. Ti byli vybíráni bud' selektivně, na základě kritéria, že se chovatelstvím zabývají, nebo náhodně ( $v$ rozhovoru bylo pokračováno, když se ukázalo, že se dotyčný pedagog k tématu chce vyjádřit); několik pedagogických pracovníků se přihlásilo z vlastní iniciativy (na výzvu v časopise). Rozhovor byl s respondenty veden volně, tj. nestrukturovaně, aby měli možnost vyjádřit své názory na danou problematiku, své pozitivní i negativní zkušenosti atd. Na základě rozhovorů byly vysloveny výzkumné otázky, jimiž byly rozhovory (prostřednictvím jejich zápisu) druhotně analyzovány. $V$ několika prípadech byla využita možnost opakovaného rozhovoru (tj. metoda pořizování vzorků vycházející z budované teorie, viz Strauss, Corbinová, 1999: str. 131-144).

Studium dokumentů: Celkem bylo v roce 2007 studováno 30 seminárních prací na téma „Environmentální výchova na naší škole", zadávaných studentům kombinovaného studia $v$ rámci předmětu Základy ekologie a problematiky životního prostředí, který je vyučován na katedře biologie a ekologické výchovy UK-PedF. Studenti měli při vyhotovení práce značnou volnost. Zápis do předmětu lze považovat (ve vztahu k danému výzkumu) za náhodný. Autoři prací vyučují nejen na prvním stupni ZŠ, ale také v MŠ a speciálních ZŠ apod.

Ohniskové skupiny: Téma bylo otevřeno v devíti ohniskových skupinách tvořených 12 až 40 učiteli a učitelkami. Význam této metody je především v doplňování a ověřování údajů získaných rozhovory (podrobně popsané viz. Strauss, Corbin, 1999: str. 37-38).

\section{Výzkumné otázky:}

- Jaké př́nosy a jaká rizika chovu exotických zvířat $v$ českých školách pedagogové zmiňují?

- Jaká zvířata jsou chována nejčastěji?

- Jaká kritéria uvažují učitelé při výběru zvířat?

- Kdo o zvířata pečuje? 
- Je problémem péče o víkendech a prázdninách?

- Je chov mazlíčků skutečně na vzestupu?

- Jaké jsou důvody pro pořízení mazlíčka do třídy?

- Jaké jsou důvody pokračování/zrušení chovu?

- Jak učitelé řeší přemnožení chovaného druhu?

- Co je potřeba $v$ této oblasti zlepšit?

\section{Výsledky}

Ve třídách respondentů byly zaznamenány následující chovy: akvária s rybičkami a s dalšími sladkovodními živočichy a rostlinami; a tato zvířata: křečci, zakrslí králíci, morčata, pískomilové, žáby, želvy suchozemské i vodní, strašilky, pakobylky, oblovky, žížaly (v kompostéru), korely, andulky, pes. ${ }^{1}$

Zviŕata využitá $v$ návštěvních programech ve třídách respondentů byla zaznamenána tato: psi učitelů i s psovodem (canisterapeutičtí), morčata, křečci, králíci, pískomilové, zakrslí králíci, bílá myš, želvy, hadi.

Při výběru druhu chovaného zvířete učitele základní školy nejvíce ovlivňuje nutnost respektovat alergického žáka, dostupnost (především cena) a kupodivu v naprosté většině prípadů i náhoda. Učitelé obvykle předem nezvažují nároky na péči o daného živočicha, hluk a zápach, který zviŕ̌e, resp. jeho ubikace vydává. Učitelé ne vždy předem odhadnou, co je při péči o vybraného živočicha čeká (např. motorek vzduchování akvária je ve tř́́dě nečekaně ruší při výkladu).

O zvířata v pracovních dnech školního roku pečují pod dozorem učitele žáci. Ti se bud' v péči stř́idají (",chovatelská služba"), nebo ne (stálá péče vybraných žáků). Péče o víkendech a prázdninách je i není vnímána jako problém. Obvyklé rešení prázdninové péče: žáci si berou mazlíčky domů nebo vypomáhá školník. O prázdninách hyne nejvíce zvírat ze školních chovů.

V některých třídách žáci mají fyzický kontakt (hlazení, pochování) s drobnými savci či želvami povolen, $v$ jiných ne. Ve třídách $s$ postiženými žáky je vyšší riziko zabití zvírete žáky. $V$ rozhovorech zabití zmínili dva pedagogové. Jednou z nich byla učitelka ze speciální školy zaměřené na autisty, která následně chov zrušila a zavedla pouze návštěvní programy za stálého dohledu pedagoga a zooasistenta. Druhým byl učitel ze základní a speciální školy zaměřené na děti S SPU a ADHD. Ten ve snaze o třídní chov (akvárium s rybičkami) vydržel. Jeho slovy: "V prvním roce nebylo neobvyklé, že žáci rozmazávali rybičky o stěny akvária, ale pak se o ně začali starat. Dnes při péči o akvárium takřka nepotřebují pomoc a podařilo se jim rozmnožit celou radu druhư akvarijních ryb. Jsem na jejich pokrok pyšný."

Neruší zvíře ve třídě? Učitelé, kteří se zúčastnili debaty na toto téma $v$ ohniskových skupinách, aniž by sami měli nějaké zkušenosti s chovem třídního mazlíčka, se nejčastěji ptali, zda zviŕre ve třídě neruší pozornost žáků. Učitelé se zkušeností s chovem, kteří se na každé ohniskové skupině vyskytli, jim odpovídali, že neruší, naopak; a uváděli konkrétní př́klady, jak zviŕ̌̌e ve třídě napomáhá při procesu učení.

Nejčastěji uváděná pozitiva. Učitelé uvádí, že dětem vztah k zvířeti prospívá psychicky (zklidnění, omezení stresu), fyzicky (poskytuje př́ležitost a motivaci k rozvoji

\footnotetext{
${ }^{1}$ Vzhledem $\mathrm{k}$ tomu, že učitelé nepoužívali odborné vědecké názvy zvířat, nejsou ani $\mathrm{v}$ tomto výčtu používány.
} 
jemné motoriky) i sociálně (pravidelná péče o zvíře buduje pozitivní osobnostní rysy, např. schopnost vcítění a úctu k životu, zodpovědnost, pracovní dovednosti). Přítomnost zvířete ve trrídě pozitivně ovlivňuje celkové sociální klima třídy (posiluje komunikaci a spolupráci žáků) a navyšuje spolupráci mezi školou a rodinami žákư. Přítomností zvířete ve třídě žáci nejsou rušeni (soustředí se na práci, i když je např. pískomil v teráriu zrovna aktivní). Jedna učitelka popsala humánně-animální interakci takto:"Ti největší roštáci a hulváti, když si vezmou do dlaní mlád’ata křečka, jsou opatrní a něžní."

Nejčastěji uváděná negativa. Překážkou chovu je žák s rozvinutou alergií, kterého je nutné respektovat.

Další zjištění. Rodiče žáků mají i nemají pro chov pochopení. Vedení školy má i nemá pro chov pochopení. Pokud je chov z nějakého důvodu ve škole ukončen, zvířátko si nejčastěji bere do domácí péče některý z žáků. Nedbale vedené školní chovy působí kontraproduktivně (snižují schopnost vcítění a úctu k životu), proto, pokud není zaručeno plnění základních potřeb zvíře, je lepší zvířata nechovat. V tomto případě je vhodné umožnit žákům jiný kontakt se zvířaty, např. možnost pozorování (nebo i přikrmování) volně žijících zvířat, návštěvní programy ve trrídě nebo v rodinách či v ekocentrech.

Při namnožení chovaných zvířat jsou mlád’ata bud' rozdána, prodána do speciálního obchodu nebo (sic!) vypuštěna do přírody.

Učitelé obvykle neřeší problém welfare chovaných zvírat. Přemýšlení o tom, jak se zvíře ve třídě cítí, zda se mu dobře daří, zda nemá stres, nebylo zaznamenáno často. Pouze jedna učitelka na ohniskové skupině vystoupila s prohlášením, že ona nemá ve třídě zvíre záměrně, aby ho netrápila hlukem a přílišnými doteky a vyrušováním od dětí (ohnisková skupina 13. 6. 2007). Výše popsaný př́pad (opakované zabití rybiček) ze třídy s žáky s SPU ukazuje, že někteří učitelé jsou ochotni využít zvíře jako nástroj osobnostního rozvoje až k (nebo za) hranici toho, co je eticky správné.

\section{Výsledky sebrané ze studia dokumentů k výzkumu „Živý tvor ve třídě"}

Z třiceti náhodně vybraných školských zařízení na devíti chov zvířat již existuje, v sedmi ho plánují nebo by si ho přáli, v dalších sedmi vlastního třídního mazlíčka nemají, ale nejrůznější živí tvorové u nich ve třídě byli na jednodenní až týdenní návštěvě, resp. návštěvním programu. $V$ jednom případě chov ( $v$ souvislosti se změnou školníka) zrušili (viz tabulka), v dalším př́ípadě neobnovili chov savce (křeček byl nevrlý), ale mají chov oblovek. ${ }^{2}$

\section{Tabulka: Studium dokumentů k výzkumu „Živý tvor ve třídě".}

(Úkolem učitelů bylo popsat stav environmentální výchovy na svém pracovišti. Tj. nebyli výslovně vyzváni, aby zmínili chovy exotů.)

\begin{tabular}{|l|l|l|l|}
\hline $\begin{array}{l}\text { Číslo } \\
\text { (zkratka) }\end{array}$ & $\begin{array}{l}\text { Mazlíčka ve } \\
\text { třídě } \\
\text { mají/nemají }\end{array}$ & $\begin{array}{l}\text { Jakého / důvod proč } \\
\text { nemají }\end{array}$ & Poznámka \\
\hline 1 (MŠ 1) & $\begin{array}{l}\text { Nemají. } \\
\text { Vypůjčují od }\end{array}$ & $\begin{array}{l}\text { Ředitelka má strach } \\
\text { z negativních reakcí }\end{array}$ & $\begin{array}{l}\text { Učitelka vyzývá děti, aby } \\
\text { přinesly zvíŕátka na dva dny }\end{array}$ \\
\hline
\end{tabular}

\footnotetext{
${ }^{2} \mathrm{~V}$ ostatních seminárních pracích se tomuto tématu respondenti nevěnovali.
} 


\begin{tabular}{|c|c|c|c|}
\hline & $\begin{array}{l}\text { žáků na } \\
\text { několik dnů. } \\
\text { Do budoucna } \\
\text { o jeho } \\
\text { pořízení } \\
\text { uvažují. }\end{array}$ & $\begin{array}{l}\text { rodičů. } \\
\text { Negativní zkušenost } \\
\text { s akváriem, které prasklo } \\
\text { a způsobilo škodu. }\end{array}$ & $\begin{array}{l}\text { jako hosty na návštěvní } \\
\text { program (ve třídě již měli } \\
\text { křečka, zakrslého králíka, } \\
\text { bílou myšku, morčata, } \\
\text { hlemýždě). } \\
\text { Nepřítomnost zvířete ve třídě } \\
\text { kompenzuje zvýšenou } \\
\text { pozorností věnovanou } \\
\text { zvířatům v okolí školky } \\
\text { (pozorují kachny divoké, } \\
\text { motýly, brouky, kosy, } \\
\text { hlemýždě). }\end{array}$ \\
\hline 2 (MŠ 2) & Nezmiňuje. & $\begin{array}{l}\text { (V práci tato učitelka } \\
\text { především srovnává } \\
\text { zkušenosti z venkovské } \\
\text { a městské MŠ.) }\end{array}$ & $\begin{array}{l}\text { Pozorují venkovní živočichy, } \\
\text { které krátkodobě chovají i ve } \\
\text { třídě („drobný hmyz"). } \\
\text { Popisuje návštěvy Zoo, } \\
\text { medvědů v Berouně, koní na } \\
\text { Zmrzlíku, pozorování ptákư } \\
\text { na krmítku. }\end{array}$ \\
\hline $\begin{array}{l}3 \text { (MŠ } 3 \text { - } \\
\text { speciální MŠ) }\end{array}$ & Nemají. & $\begin{array}{l}\text { Učitelka má strach, že by } \\
\text { děti s autismem zvíře } \\
\text { ohrožovaly. }\end{array}$ & $\begin{array}{l}\text { Učitelka vnímá, že děti po } \\
\text { mazlíčkovi touží. }\end{array}$ \\
\hline $\begin{array}{l}4 \text { (MŠ } 4 \\
\text { Waldorfská) }\end{array}$ & Mají. & $\begin{array}{l}\text { Dvě morčata. } \\
\text { V létě je chovají v ohrádce } \\
\text { na zahradě, v zimě v kotci } \\
\text { ve vestibulu školky. }\end{array}$ & $\begin{array}{l}\text { Děti se o morčata starají, } \\
\text { chovají je a hladí. Z domova } \\
\text { jim nosí pamlsky. Na } \\
\text { prázdniny se morčata stěhují } \\
\text { vždy k někomu z dětí. } \\
\text { Mj. s dětmi jezdí pravidelně } \\
\text { na statek za domácími } \\
\text { zvířaty. }\end{array}$ \\
\hline 5 (MŠ 5) & Nemají. & --- & $\begin{array}{l}\text { Návštěvy stanice výcviku } \\
\text { slepeckých psů, zoO, } \\
\text { Toulcova dvora, přírodovědná } \\
\text { stanice v Jinonicích. }\end{array}$ \\
\hline 6 (MŠ 6) & $\begin{array}{l}\text { Nemají, ale } \\
\text { plánují. }\end{array}$ & $\begin{array}{l}\text { Naplánováno: želvičky, } \\
\text { strašilky, rybičky. }\end{array}$ & $\begin{array}{l}\text { Pozorování ptáků na krmítku, } \\
\text { pozorování veverek, srnek. }\end{array}$ \\
\hline 7 (MŠ 7) & $\begin{array}{l}\text { Nemají, ale } \\
\text { plánují. }\end{array}$ & $\begin{array}{l}\text { Naplánováno: akvárium, } \\
\text { terárium. }\end{array}$ & $\begin{array}{l}\text { Pozorování drobných } \\
\text { živočichů (hmyzu a žížal), } \\
\text { krmítko pro ptáky a } \\
\text { pozorování ptákư na krmítku. } \\
\text { ZOO. }\end{array}$ \\
\hline $\begin{array}{l}8 \text { (MŠ } 8 \\
\text { ortooptická } \\
\text { třída) }\end{array}$ & Mají. & $\begin{array}{l}\text { Akvárium (rybičky aj.) } \\
\text { ve třídě. }\end{array}$ & Společná péče. \\
\hline 9 (MŠ 9) & Nezmiňuje. & $\begin{array}{l}\text { Venkovská školka - } \\
\text { kontakty se zvířaty mají } \\
\text { děti v rodině. }\end{array}$ & $\begin{array}{l}\text { Krmení ptáků na krmítku, } \\
\text { krmení zvěře v lese } \\
\text { (spolupráce s lesníky). }\end{array}$ \\
\hline 10 (MŠ 10) & $\begin{array}{l}\text { Nemají, ale } \\
\text { plánují. }\end{array}$ & $\begin{array}{l}\text { Naplánováno: akvárium, } \\
\text { housenárium. }\end{array}$ & $\begin{array}{l}\text { Krmítko pro ptáčky. Hnízda } \\
\text { vlaštovek na školce - }\end{array}$ \\
\hline
\end{tabular}




\begin{tabular}{|c|c|c|c|}
\hline & & & $\begin{array}{l}\text { pozorování. Starají se } \\
\text { o krmelec v blízkosti MŠ. } \\
\text { Navštěvují rodiny dětí, v nichž } \\
\text { se právě narodila nějaká } \\
\text { mlád’ata. ZOO. }\end{array}$ \\
\hline 11 (MŠ 11) & Nezmiňuje. & --- & $\begin{array}{l}\text { Pozorování kachen, veverek, } \\
\text { ptáků, brouků, žížal. } \\
\text { Pozorování ptáků na krmítku. }\end{array}$ \\
\hline 12 (ZŠ 1 ) & $\begin{array}{l}\text { Nemají. } \\
\text { Žáci ale nosí } \\
\text { na jednodenní } \\
\text { návštěvy } \\
\text { domácí } \\
\text { mazlíčky. }\end{array}$ & $\begin{array}{l}\text { Obava z alergií. Odpor } \\
\text { školníka. }\end{array}$ & Návštěvy ZOO. \\
\hline 13 (ZŠ 2) & Nezmiňuje. & Nezmiňuje. & $\begin{array}{l}\text { Pozorování ptáků na krmítku. } \\
\text { Pozorování hmyzu na zahradě } \\
\text { (včely), na louce a v lese } \\
\text { (mraveniště), vodního ptactva } \\
\text { (labutě a kachny). }\end{array}$ \\
\hline 14 (ZŠ 3) & Nezmiňuje. & Nezmiňuje. & Nezmiňuje. \\
\hline 15 (ZŠ 4) & $\begin{array}{l}\text { Nemají. } \\
\text { Děti ale nosí } \\
\text { domácí } \\
\text { mazlíčky na } \\
\text { týdenní } \\
\text { návštěvy. }\end{array}$ & $\begin{array}{l}\text { Venkovská školka - } \\
\text { kontaktů se zvíraty mají } \\
\text { děti dost. }\end{array}$ & $\begin{array}{l}\text { Učitelka uvádí, že "žáci jsou } \\
\text { v každodenním kontaktu } \\
\text { s různými druhy domácích } \\
\text { zvírat, jako jsou slepice, } \\
\text { kachny, husy, krocani, býci, } \\
\text { telata, krávy, ovce, berani, } \\
\text { koně, včely, kočky, psi. Znají } \\
\text { však i způsob chování myší, } \\
\text { krys a potkanů. Nebo ježkü, } \\
\text { žab, slepýšù. Pro ptáky vyrábí } \\
\text { s tatínky budky a krmítka. } \\
\text { Navštěvují farmáře. Pozorují } \\
\text { venku mravence, hmyz, } \\
\text { ptáky, vodní ptáky, včely." }\end{array}$ \\
\hline $\begin{array}{l}13 \text { (Jedličkův } \\
\text { ústav - děti } \\
\text { od MŠ do SŠ) }\end{array}$ & Nezmiňuje. & --- & Nezmiňuje. \\
\hline $\begin{array}{l}14 \text { (MŠ } \\
\text { sluchově } \\
\text { postižené) }\end{array}$ & Nezmiňuje. & --- & $\begin{array}{l}\text { Skladují zbytky svačin a krmí } \\
\text { s nimi zvírata. Učitelka by } \\
\text { ráda zrealizovala návštěvu } \\
\text { králíků pana školníka (ale ten } \\
\text { nesouhlasí). }\end{array}$ \\
\hline 15 (SpŠ) & Nezmiňuje. & --- & Nezmiňuje. \\
\hline 16 (ZŠ 5) & $\begin{array}{l}\text { Nemají. } \\
\text { Chtěli by. } \\
\text { Vypůjčují od } \\
\text { žáků na } \\
\text { několik dnů. }\end{array}$ & $\begin{array}{l}\text { Problém: prostor, péče } \\
\text { o prázdninách. }\end{array}$ & $\begin{array}{l}\text { Návštěvy Toulcova dvora, } \\
\text { farmy na Zemědělské vysoké } \\
\text { škole, útulku pro zvířata. } \\
\text { Zvou odborníky (myslivce, } \\
\text { včelaře). }\end{array}$ \\
\hline
\end{tabular}




\begin{tabular}{|c|c|c|c|}
\hline $\begin{array}{l}17 \text { (Domov } \\
\text { pro mentálně } \\
\text { postižené) }\end{array}$ & Mají. & $\begin{array}{l}\text { Hospodářská zvířata } \\
\text { (koně, kozy, pes, kočky, } \\
\text { králíci, početné } \\
\text { včelstvo) poskytují užitek } \\
\text { jako mazlíčci i jako } \\
\text { potrava. Pečují o ně } \\
\text { zaměstnanci školy } \\
\text { a dospělí klienti (koně, } \\
\text { kozy) i děti (kočky). }\end{array}$ & $\begin{array}{l}\text { Pozorování veverek, zajíců, } \\
\text { srnek. }\end{array}$ \\
\hline $\begin{array}{l}18 \text { (ZŠ } 6 \\
\text { speciální) }\end{array}$ & Nezmiňuje. & --- & $\begin{array}{l}\text { Pomoc místnímu svazu } \\
\text { myslivců při přípravě potravy } \\
\text { pro lesní zvěř na zimu. } \\
\text { Návštěvy ZOO. }\end{array}$ \\
\hline $\begin{array}{l}19 \text { (Domov } \\
\text { Maxov) }\end{array}$ & $\begin{array}{l}\text { Mají a uvažují } \\
\text { o rozšírení. }\end{array}$ & $\begin{array}{l}\text { Vlastní zvířata klientů: } \\
\text { psy, kočky, želvy, } \\
\text { andulky, rybičky. } \\
\text { Mají možnost chovu } \\
\text { domácích hospodářských } \\
\text { zvířat. }\end{array}$ & $\begin{array}{l}\text { V Domově mohou obyvatelé } \\
\text { vlastnit domácí zvířata, } \\
\text { podmínkou je, že mají zájem } \\
\text { o ně pečovat a jsou toho } \\
\text { schopní. } \\
\text { Obyvatelé s těžším postižením } \\
\text { jsou závislí na dobré vưli } \\
\text { asistentů pečovat o zvířata } \\
\text { místo nich. }\end{array}$ \\
\hline 20 (ZŠ 7) & $\begin{array}{l}\text { Nemají, ale } \\
\text { měli. }\end{array}$ & $\begin{array}{l}\text { Bývalý školník měl atrium } \\
\text { s orlem, supem atd. Nový } \\
\text { školník nechce. }\end{array}$ & \\
\hline $\begin{array}{l}21 \text { (Domov } \\
\text { pro děti s } \\
\text { mentálním } \\
\text { postižením) }\end{array}$ & $\begin{array}{l}\text { Mají užitkové } \\
\text { zvířata. Exoty } \\
\text { nemají, chtěli } \\
\text { by. }\end{array}$ & $\begin{array}{l}\text { Vepře. Exoty nemají, ale } \\
\text { chtěli by. Nedostatek } \\
\text { prostoru. } \\
\text { Obavy z hygienika či } \\
\text { poranění (v případě } \\
\text { skleněného akvária) dětí. }\end{array}$ & $\begin{array}{l}\text { Sběr kaštanů pro lesní zvěř. } \\
\text { Zbytky z kuchyně pro vepře. }\end{array}$ \\
\hline $\begin{array}{l}22 \text { (Speciální } \\
\text { MŠ, ZŠ a SŠ) }\end{array}$ & Mají. & $\begin{array}{l}\text { Pes canisterapeutický } \\
\text { vlastní. }\end{array}$ & $\begin{array}{l}\text { Návštěvy Toulcova dvora, } \\
\text { ZOO. }\end{array}$ \\
\hline $\begin{array}{l}23 \text { (dílna pro } \\
\text { mentálně } \\
\text { postižené) }\end{array}$ & $\begin{array}{l}\text { Nemají, } \\
\text { návštěvy psa. }\end{array}$ & $\begin{array}{l}\text { Canisterapeutka dochází } \\
\text { se psem 1x měsíčně. }\end{array}$ & \\
\hline 24 (SŠ) & Nezmiňuje. & --- & \\
\hline $\begin{array}{l}25 \text { (MŠ a ZŠ } \\
\text { spec.) }\end{array}$ & $\begin{array}{l}\text { Nemají, ale } \\
\text { plánují. }\end{array}$ & $\begin{array}{l}\text { Plánují: pakobylky, } \\
\text { rybičky. }\end{array}$ & $\begin{array}{l}\text { Projekt Terezy Les ve škole, } \\
\text { škola v lese. Nosí krmení } \\
\text { divoké zvěři ke krmelcưm. } \\
\text { Zbytky z kuchyně nosí } \\
\text { zvířatüm ve vesnici. }\end{array}$ \\
\hline 26 (MŠ) & $\begin{array}{l}\text { Mají. } \\
\text { Uvažovali } \\
\text { i o mazlíčkovi } \\
\text { do třídy. }\end{array}$ & $\begin{array}{l}\text { Dvě kočky, které si je } \\
\text { "adoptovaly". Mazlíčky ve } \\
\text { třídě si nepoŕídí, i když by } \\
\text { chtěli (dotazníkem zjistili } \\
\text { nesouhlas několika } \\
\text { rodičů). }\end{array}$ & Pozorování ptáků na krmítku. \\
\hline
\end{tabular}




\begin{tabular}{|c|c|c|c|}
\hline 27 (MŠ) & Mají. & $\begin{array}{l}\text { Akvárium s rybičkami } \\
\text { a žabkami. }\end{array}$ & $\begin{array}{l}\text { Děti samy krmí rybičky, } \\
\text { sledují žabky. } \\
\text { Možnost vidět v rodinných } \\
\text { domcích okolo MŠ některá } \\
\text { domácí zvířata. Možnost } \\
\text { pozorovat volně žijící zvířata } \\
\text { (labutě, zajíce, bažanty, } \\
\text { srny). }\end{array}$ \\
\hline 28 (MŠ) & $\begin{array}{l}\text { Nemají. } \\
\text { Návštěvní } \\
\text { programy. }\end{array}$ & --- & $\begin{array}{l}\text { Pozorování ptáků na krmítku. } \\
\text { Pozorování ptačích stop. Na } \\
\text { poslední návštěvě měli hady. }\end{array}$ \\
\hline $\begin{array}{l}29 \text { (MŠ } \\
\text { integrovaná) }\end{array}$ & Nemají. & $\begin{array}{l}\text { Kynolog se psy dochází } \\
2 x \text { ročně. } \\
\text { Děti s autismem by se } \\
\text { mohly zranit o sklo nebo } \\
\text { ublížit zvíreti. }\end{array}$ & $\begin{array}{l}\text { Návštěvy psího a kočičího } \\
\text { útulku. Návštěva lesa s } \\
\text { myslivcem. Sběr krmení } \\
\text { (kaštanů, žaludů) do krmelce. }\end{array}$ \\
\hline 30 (ZŠ a MŠ) & $\begin{array}{l}\text { Mají (,jjen } \\
\text { oblovky"). } \\
\text { Návštěvní } \\
\text { programy. }\end{array}$ & $\begin{array}{l}\text { Oblovky. Měli křečka, ale } \\
\text { kousavého, takže si ho } \\
\text { děti nemohly ani pohladit } \\
\text { a jejich zájem uvadl. }\end{array}$ & $\begin{array}{l}\text { Návštěvní programy "Den } \\
\text { zvířat", kdy si děti mohly do } \\
\text { školy přinést svoje zvíře } \\
\text { a představit ho. } \\
\text { Pokud je to možné, bereme } \\
\text { aktuálně probírané zviŕe do } \\
\text { výuky. } \\
\text { Program s dravými ptáky. }\end{array}$ \\
\hline
\end{tabular}

\section{Vybrané kasuistiky}

\section{Králík do školy nesměl}

Jeden dyslektický žák chtěl spolužákům ukázat svého králíka. Byl to jediný způsob, jak by mohl být ve škole chvíli úspěšný. Paní ředitelka to zakázala. Rodiče žáka zanedlouho přehlásili na jinou školu (Ohnisková skupina 13. 6. 2007).

\section{Pes Tomík}

Pravděpodobně první třídou prvního stupně ZŠ v ČR, do které denně dochází pes, je 3. C v ZŠ Ústavní. Yorkshirský teriér Tomík ${ }^{3}$ dochází s paní učitelkou I. R. do školy již sedmým rokem. Paní učitelka do projektu vstoupila před více než pěti lety na žádost svých bývalých žáků. Ti za Tomíkem chodí stále na návštěvu, ale neměli problém ho přenechat budoucím prvňáčkům. Nejen děti, ale i rodiče jsou z projektu nadšení. Kolegové, kolegyně a především pan ředitel ZŠ Ústavní jej podporují. Z diskusí zveřejněných na webových stránkách a z rozhovoru $s$ matkou jednoho žáka je patrné nadprủměrné psychosociální klima třídy.

\footnotetext{
${ }^{3}$ Více na webových stránkách třídy: http://www.zsustavni1c.estranky.cz/
} 


\section{Korela Štístko}

Učitelka Inka (koordinátorka EVVO) ze ZŠ Antonína Sochora Duchcov měla ve třídě tři školní roky korelu (obr. 1), kterou jako mládě žákům pořídila (po konzultaci s ředitelstvím školy a rodiči) na začátku první třídy (více z jejího prvního dopisu):

„.... přinesla svým žákưm $v$ tehdejší 1 . třídě dvouměsíční korelu. Dali jí jméno Štístko. Dnes ji mají už třetí rok a milují ji nadevše. Stř́dají se po skupinkách a pečují o ni (jídlo + voda + čištění klece), mají ji velmi ochočenou a dokonce ji naučili i mluvit (zřetelně vyslovuje své jméno). Pouštíme ji hned $v$ osm hodin a o poslední přestávce ji žáci sami uklízí do klece. Mohu všem jenom doporučit mít živého tvora ve tř́idě. Děti jsou nucené se chovat podle toho, nelítají po třídě, nekřičí a rozvijí se jim hezký vztah $k$ prírodě.

Negativní stránku vidím pouze $v$ tom, když je někdo alergik. $v$ této tř̌́dě naštěstí nikdo. Dále mají děti ještě akvárium, kde také o přestávkách pozorují rybičky, žabičku a krevetky."

Čtvrtým rokem ale bohužel experiment „pták ve třídě" skončil. Opět z dopisu: "bohužel se určitým nejmenovaným lidem na škole Štístko nezdál, vzhledem k tomu, že prý rušil $v$ hodině (nebyla to pravda, pouze když přišel někdo nový do třídy...)" Paní učitelka pak místo korely pořídila dětem želvy (obr. 3 ).

\section{Obr.1 Korela Štístko a želva Želva - společníci žáků Zš Antonína Sochora Duchcov. Fotografie H. Kykalová.}
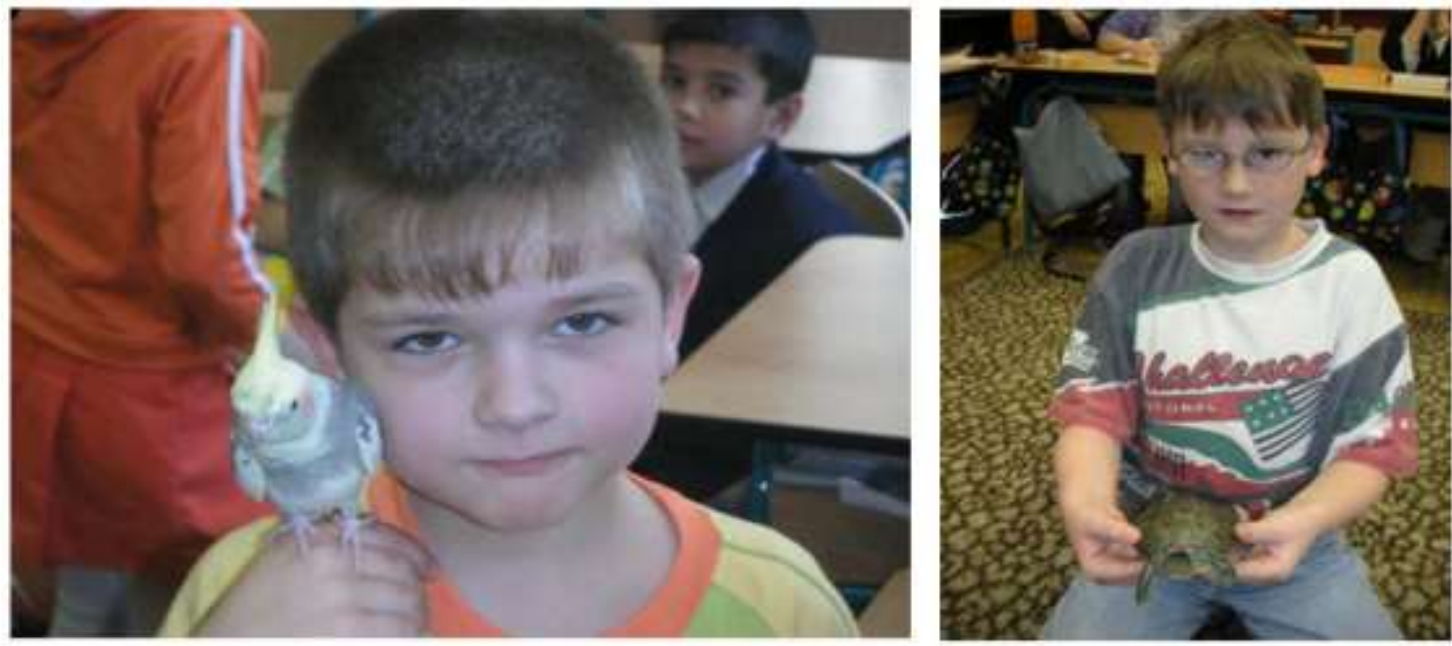

\section{Diskuse}

Pozitiva chovu exotických zviŕat ve školách můžeme klasifikovat bud' na úrovni jedince - konkrétního žáka, nebo na úrovni třídního kolektivu. Na úrovni jedince dochází k rozvoji environmentální senzitivity, rozvoji klíčových kompetencí a dalších osobnostních charakteristik a také ke zklidnění, odbourávání stresu a ke zlepšení postoje ke škole (žák se do školy více těší). Na úrovni třídního kolektivu dochází ke zlepšení komunikace (je nutná domluva, kdo poskytne péči apod.). Žáci se učí pracovitosti a prítomnost zvírete ve tř́ídě Ize využít $\mathrm{k}$ demonstraci mnoha přirozených jevů a cyklů (sekání trávy, kompostování podestýlky, hnojení trávníku, smrt). Žáci se prostřednictvím kontaktu s živým tvorem přibližují prírodě. Zvyšuje se také komunikace a spolupráce mezi školou a rodinou (rodina pomáhá dítěti v prázdninové péči nebo umožní návštěvu rodinného mazlíčka ve škole). 
Negativa chovu exotických zvířat ve školách můžeme klasifikovat na globální a lokální. Globální negativa spočívají v riziku, že učitelé budou více podceňovat potřebu žáků trávit čas ve venkovním prostředí. Jenže ani třída s mnoha živými tvory $v$ teráriích a akváriích nemůže plnohodnotně nahradit skutečnou komplexitu prírodních ekosystémů. Paradoxně tak může docházet k hlubšímu odcizování dětí od přírody. Následkem je přehnaná biofilie (např. podvědomé popírání existence potravního řetězce a smrti). Globálním negativem je také posun od chovu užitkových zvířat, který byl na školách tradičně veden (např. Řehák, 1967) až do 60. let 20. století, k chovu zvírat exotických. Zvyšuje se neznalost hospodářských zvírat (Jedna učitelka v rozhovoru uvedla: "Dnešní děti považují za domácí zvíře křečka, ne ovci.") a také se prohlubuje vykořenění z tradičních funkčních systémů (soběstačné hospodaření) a zvyšuje se ekologická stopa současného člověka (dovážené maso je vždy pro životní prostředí větší zátěží než maso z vlastního chovu). Lokální negativa se projevují při neodborně vedeném chovu. Jedná se především o inhibici rozvoje environmentální senzitivity, kterou způsobuje ztotožnění se s nekvalitní péčí, at' už se jedná o týrání zvířat (např. žízní), nebo dlouhodobé nerespektování jejich potřeb (časté a nadměrné vyrušování, nedostatek prostoru, nevyvážená strava, nešetrná manipulace). Významným negativem je také riziko přemnožení a nevhodné nakládání s chovatelským přebytkem (především vypouštění do volné př́rody). Významným negativem je nevhodný jedinec (zde nevrlý a kousavý křeček zlatý). Negativa je možné eliminovat vzděláváním učitelů, a to $v$ oblastech: výběr vhodného druhu, výběr vhodného jedince, optimalizace péče o konkrétní druh, nakládání s chovatelskými přebytky, snižování ekologické stopy chovu, didaktické využití přítomnosti živého tvora ve třídě.

Za podmínky, že je asistenční (at́ již chovaný nebo navštěvující) druh i jedinec vhodně vybrán, že je zajištěno jeho welfare, je prítomnost živého tvora ve třídě přínosem pro celkový psychosociální rozvoj žáků, a pro sociální klima třídy i pro navýšení spolupráce škola-rodina ji Ize jen doporučit.

\section{Závěr}

Lidé dnes často odcizením od přírody trpí, aniž by si je uvědomovali nebo aniž by byli schopni sami sobě pomoci (např. pacienti LDN). Na jejich potřeby odpovídá masivní rozvoj zooterapií a zooasistenčních aktivit v zahraničí (např. Odendaal, 2007) i u nás (např. Svobodová, 2008, Chvátalová, 2003, Galajdová, 1999). Jak dokazuje zde prezentovaný výzkum, v českých školách byl zaznamenán trend, který by se mohl nazvat „návrat k chovatelství". Dưvodem „návratu k chovatelství" se jeví snaha o kompenzaci procesu odcizování přírodě a jeho (především psychických nebo psychosociálních) následků. Chov třídního mazlíčka ale nelze chápat jako komplexní řešení problému odcizení, nýbrž jen jako řešení dílčí.

V této oblasti se otevírá jednak významné výzkumné pole a také potřeba dalšího vzdělávání učitelů, aby byl potenciál AAE aktivit co nejvyšší a aby byla minimalizována jeho rizika (Jančaříková, 2008). Na základě tohoto zjištění byl koncem roku 2009 na UKPedF v rámci Celoživotního vzdělávání akreditován kurz Potenciál zooasistencí v pedagogické praxi, do několika pregraduálních i postgraduálních kurzů zařazen informativní blok o pozitivních účincích humánně animálních interakcí i interakcích dítě živý tvor a byla vypsaná celá řada témat ke zpracování formou bakalářské nebo diplomové práce studentků UK-PedF v Praze. Na kurzu Potenciál zooasistencí v pedagogické praxi budou pedagogičtí pracovníci seznámeni s teorií zooasistence a zooterapií (prostřednictvím rešerší ze zahraničních odborných článků a literatury), získají informace, podle jakých kritérií vybrat vhodný druh a vhodného jedince pro zooasistenci, a seznámí se se zkušenostmi českých kolegů z praxe. Budou diskutovány výhody a nevýhody návštěvních programů a třídních chovů pro konkrétní skupiny žáků, studentů, učňů a dalších kolektivů. Učitelé budou informováni o nutnosti zajištění welfare, o pravidlech veterinární kontroly 
třídních chovů a také o správném nakládání s uhynulými nebo přemnoženými zviřaty. Během kurzu uvidí (a také si sami vyzkouší) ukázky AAE aktivit s několika druhy živočichů.

Výzkum představený $v$ tomto článku přináší tedy nejen teoretické poznatky, ale také zasahuje př́mo do vzdělávacího procesu.

\section{Literatura a zdroje}

- Bajtlerová, I. Využití canisterapie v ambulanci klinické logopedie. In Svobodová, I. aj (Ed.), Terapie a asistenční aktivity lidí za pomoci zvírat : Sborník príspěvků z odborné konference s mezinárodní účastí (pp. 58-64). Praha: Čzú.

- Baarda, B., Endenburg, N, . The Role of Pets in Enhancing Human Well-being: Effects on Child Development. . Retrieved from http://www.deltasociety.org/Document.Doc?id=25

- Dvořáková, T., \& Janura, M. (2008) Měření tlakových sil na kontaktu těla jezdce a hřbetu koně v hipoterapii. In Terapie a asistenční aktivity lidí za pomoci zviŕat : Sborník príspěvků z odborné konference s mezinárodní účastí. Praha: Čzú.

- Galajdová, L. (1990). Pes lékařem lidské duše aneb Canisterapie. Praha: Grada Publishing.

- Herzog, W. (2005). Grizzly Man. : Lions Gate.

- Chvátalová, H. (2003). Psi pro zdraví a pohodu. Děti a my, XXXIII(III), 32-33.

- Jančaříková, K. (2008). Environmentální výchova na prvním stupni ZŠ. Praha: UK-PedF.

- Jančaříková, K. (2008). Př́lohy disertační práce. Praha: UK-PedF.

- Kučera, M. (2005). Pražská skupina školní etnografie : Psychický vývoj dítěte od 1. do 5. tř́dy. Praha: Karolinum.

- $\quad$ Lévi-Strauss, C. (1996). Myšlení přirodních národů. Praha: Dauphin.

- Odendaal, J. (2007). Zviŕata a naše mentální zdraví : Proč, co a jak. Praha: Brázda.

- Řehák, B. (1967). Vyučování biologii na základní devítileté škole a střední všeobecné škole : Př́spěvek k didaktice biologie. Praha: Svoboda.

- Sak, P. (2000). Proměny české mládeže. Praha: Petrklíč.

- Smrčková, L., \& Smrček, M. (1990). Začínáme se zvíraty. Praha: Státní zemědělské nakladatelství.

- Strauss, A., Corbin, J, (1998). Basics of Qualitative Research : Techniques and Procedures for Developing Grounded Theory. London.

- Strauss, A., \& Corbinová, J. (1999). Základy kvalitativního výzkumu. Brno: Podané ruce.

- Svobodová, I. aj, (2008). Terapie a asistenční aktivity lidí za pomoci zviŕat : Sborník př́spěvků z odborné konference s mezinárodní účastí. Praha: Čzú.

- Šípek, J. (2000). Projektivní metody. Praha: ISC.

- Vágnerová, M. (2000). ývojová psychologie : Dětství, dospělost, stáři. Praha: Portál.

- Velemínský, M. a kol, (2007). Zooterapie ve světle objektivních poznatků. Brno: DONA. 
Časopis Envigogika vydává Centrum pro otázky životního prostředí UK. Vývoj časopisu je podpořen projektem OP VK Mezioborová sít udržitelného rozvoje.

Více najdete na internetových stránkách projektu mosur.czp.cuni.cz
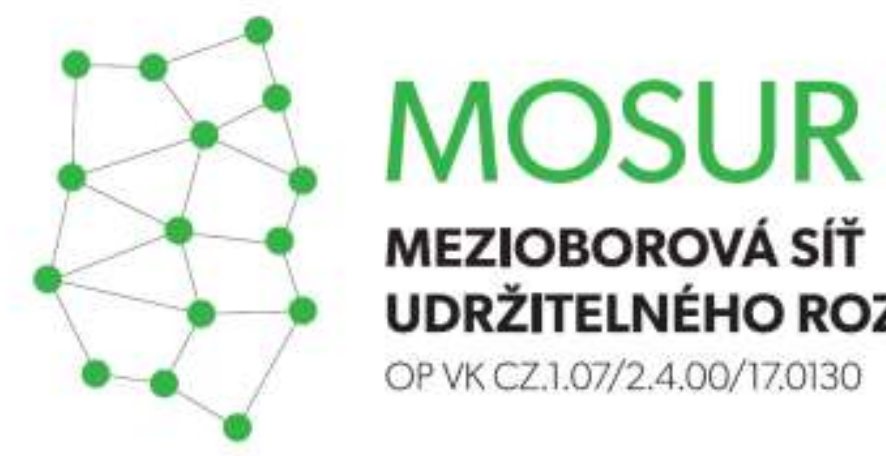

\section{MEZIOBOROVÁ SÍT} UDRŽITELNÉHO ROZVOJE

OP VK CZ.1.07/2.4.00/17.0130
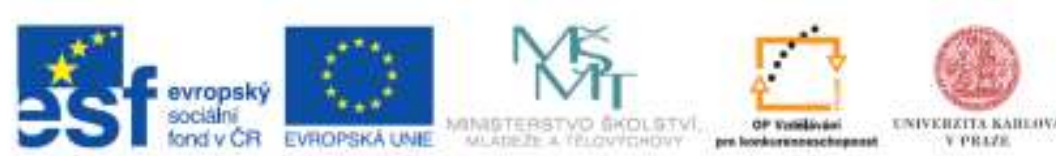

INVESTICE DO ROZVOJE VZDELAVANI 